\title{
Taxonomic notes on the genus Turkozelotes Kovblyuk et Seyyar, 2009 (Aranei: Gnaphosidae)
}

\author{
Таксономические заметки о роде Turkozelotes \\ Kovblyuk et Seyyar, 2009 (Aranei: Gnaphosidae)
}

\author{
Alexander V. Ponomarev', Kirill G. Mikhailov², \\ Vladimir Yu. Shmatko ${ }^{1}$ \\ А.В. Пономарёв ${ }^{1}$, К.Г. Михайлов ${ }^{2}$ В.Ю. Шматко ${ }^{1}$
}

\footnotetext{
${ }^{1}$ Southern Scientific Centre of the Russian Academy of Sciences, Chekhov av., 41, Rostov-on-Don 344006 Russia. E-mail: ponomarev1952@mail.ru

1 Федеральный исследовательский центр Южный научный центр Российской академии наук, пр. Чехова, 41, Ростов-на-Дону 344006 Россия.

${ }^{2}$ Zoological Museum MGU, Bolshaya Nikitskaya Str., 2, Moscow 125009 Russia. E-mail: mikhailov2000@gmail.com

2 Зоологический музей МГУ, ул. Большая Никитская, 2, Москва 125009 Россия.
}

KEY WORDS: Araneae, new synonym, new combinations, spiders, south of Russia, Azerbaijan, Kazakhstan. КЛЮЧЕВЫЕ СЛОВА: Araneae, новый синоним, новые комбинации, пауки, юг России, Азербайджан, Казахстан.

ABSTRACT. New data on the taxonomy of the genus Turkozelotes Kovblyuk et Seyyar, 2009, including a synopsis and distribution map of all the known species, are provided. Turkozelotes mirandus Ponomarev, 2011, syn.n. is synonymized with Zelotes kazachstanicus Ponomarev et Tsvetkov, 2006. Two new combinations are proposed: Turkozelotes kazachstanicus (Ponomarev et Tsvetkov, 2006) comb.n., ex Zelotes; and Turkozelotes adullam (Levy, 2009) comb.n., ex Drassyllus.

How to cite this paper: Ponomarev A.V., Mikhailov K.G., Shmatko V.Yu. 2021. Taxonomic remarks on the genus Turkozelotes Kovblyuk et Seyyar, 2009 (Aranei: Gnaphosidae) // Arthropoda Selecta. Vol.30. No.1 P.113-118. doi: 10.15298/arthsel.30.1.10

РЕЗЮМЕ. Приведены новые данные по таксономии рода Turkozelotes Kovblyuk et Seyyar, 2009, в том числе синопсис и карта распространения всех известных видов рода. Turkozelotes mirandus Ponomarev, 2011, syn.n. синонимизирован с Zelotes kazachstanicus Ponomarev et Tsvetkov, 2006. Предложены две новые комбинации: Turkozelotes kazachstanicus (Ponomarev et Tsvetkov, 2006), comb.n., ex Zelotes; и Turkozelotes adullam (Levy, 2009), comb.n., ex Drassyllus.

\section{Introduction}

The gnaphosid spider genus Turkozelotes Kovblyuk et Seyyar, 2009, initially monotypic, was established for T. microb Kovblyuk et Seyyar 2009 from Turkey [Kovblyuk et al., 2009]. Later, T. mirandus
Ponomarev in Ponomarev et Dvadnenko, 2011 was described from two males and three females from the south-eastern part of Rostov Area [Ponomarev, Dvadnenko, 2011]. The species Setaphis mccowani Chatzaki et Russell-Smith, 2017 was described from a single female from Cyprus [Chatzaki, Russell-Smith, 2017]. Recently, based on examination of a series of both sexes from Greece, the latter species was transferred to Turkozelotes [Chatzaki, 2018]. Two more species of this genus were described from both sexes: viz., $T$. attavirus Chatzaki, 2019 from Rhodos Island [Chatzaki, Van Keer, 2019], and T. noname Mazzia et Cornic, 2020 from south-eastern France [Mazzia, Cornic, 2020].

Zelotes kazachstanicus Ponomarev et Tsvetkov, 2006 was described from a single female from west Kazakhstan [Ponomarev, Tsvetkov, 2006]. A comparison of the type and additional materials on Z. kazachstanicus and T. mirandus has shown their identity.

Drassyllus adullam Levy, 2009 described from a single male from Israel [Levy, 2009] is shown to possess all the typical generic characters of Turkozelotes and hence is to be transferred to it (see below).

In this paper, we aim to establish a new synonymy in Turkozelotes, to propose two new combinations, to provide a synopsis of all the known Turkozelotes species, and to map their distribution.

Material and methods

The studied material is deposited in the Zoological Museum of the Moscow State University (ZMMU, curator: K.G. Mikhailov) and A.V. Ponomarev's personal collection (PC). Digital photographs were produced by using a camera SONY NEX-C3 attached to a MIKMED-6 optical micro- 


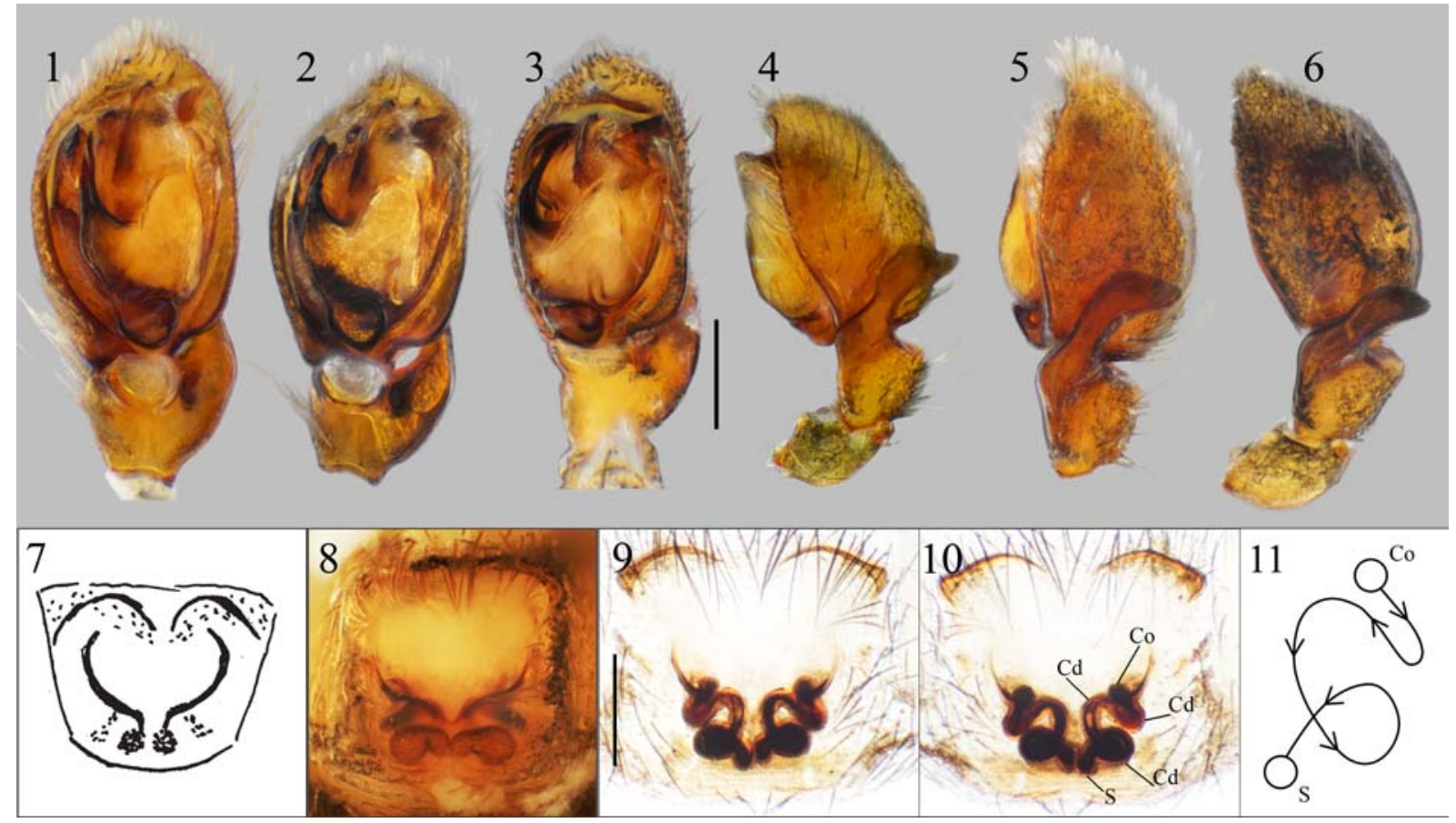

Figs 1-11. Copulatory organs of Turkozelotes kazachstanicus (Ponomarev et Tsvetkov, 2006) comb.n. 1, 5, 8 - paratypes of $T$. mirandus; 7 - holotype of T. kazachstanicus (after Ponomarev \& Tsvetkov [2006]); 2, 4 - Rostov Area; 3, 6 - Nakhichevan Republic; 9, 10 - Kustanay Area Kazakhstan: male palp ventral view (1-3) and lateral view (4-6); epigyne ventral view (7, 8); vulva, ventral (9) and dorsal views (10); schematic graph of the left copulatory duct (11). Scale: $1-6-0.25 \mathrm{~mm} ; 7-10-0.2 \mathrm{~mm}$. Cd - copulatory duct; Co copulatory opening; $\mathrm{S}$ - spermatheca.

Рис. 1-11. Копулятивные органы Turkozelotes kazachstanicus (Ponomarev et Tsvetkov, 2006) comb.n. 1, 5, 8 - паратипы T. mirandus; 7 - голотип T. kazachstanicus (по: Пономарёв, Цветков, 2006); 2, 4 - Ростовская обл.; 3, 6 - Нахичеванская республика; 9, 10 - Кустанайская обл., Казахстан: пальпа самца вентрально (1-3) и латерально $(4-6)$; эпигина вентрально $(7,8)$; вульва вентрально (9) и дорсально (10); схематическое изображение левого копулятивного протока (11). Масштаб: $1-6-0,25$ мм; 7-10-0,2 мм. Cd - копулятивный проток; Сo - копулятивное отверстие; S - сперматека.

scope at the Southern Scientific Centre of the Russian Academy of Sciences (Rostov-on-Don, Russia). The map is produced by using the online resource OpenStreetMap ${ }^{\circledR}$, containing free data that are distributed by the OpenStreetMap Foundation (OSMF) via the Open Data Commons Open Database License (ODbL).

The terminology of the Turkozelotes male palp morphology follows Chatzaki [2018]. The following abbreviations are used in the figure plates: E - embolus; EmbB - embolar base; MA - median apophysis; TA - terminal apophysis, Tm - terminal membrane; $\mathrm{p}$ - embolar process; $\mathrm{Cd}$ copulatory duct; Co - copulatory opening; S - spermatheca.

\section{Taxonomic part}

\section{Turkozelotes Kovblyuk et Seyyar in Kovblyuk, Seyyar, Demir et Topçu, 2009}

Type species Turkozelotes microb Kovblyuk et Seyyar, 2009, by monotypy.

DIAGNOSIS. See Kovblyuk et al. [2009] and Chatzaki [2018]. It should be noted that Chatzaki [2018] indicated the multipartite spermathecae to be a diagnostic character of Turkozelotes. However, according to our data (Figs 10, 11) and those of Mazzia \& Cornic [2020: 39, figs 4A,C], the spermathecae of at least in two species (viz., T. kazachstani- cus and T. noname) are unipartite.

COMPOSITION. Six species are included (Table): $T$. adullam (Levi, 2009), comb.n., T. attavirus Chatzaki, 2019, T. kazachstanicus (Ponomarev et Tsvetkov, 2006), comb.n., T. microb Kovblyuk et Seyyar 2009, T. mccowani (Chatzaki et Russell-Smith, 2017), and T. noname Mazzia et Cornic, 2020.

DISTRIBUTION. The region of Ancient Mediterranean: from the east Mediterranean to north Kazakhstan, and southward to south Iran (Table, Map).

Turkozelotes kazachstanicus (Ponomarev et Tsvetkov, 2006) comb.n. ex Zelotes

Figs 1-16, Map.

Zelotes kazachstanicus Ponomarev, Tsvetkov, 2006: 13, fig. 24 ( + ); holotype ${ }^{+}$in ZMMU, examined.

Turkozelotes mirandus Ponomarev in Ponomarev, Dvadnenko, 2011: 108, figs 1-2 $\left(\sigma^{7}+\right)$, type series in ZMMU, examined. Syn.n.

TYPES. Zelotes kazachstanicus: Holotype + (ZMMU, epigyne lost), Kazakhstan, Atyrau Area, c. 2 km NW of Makhambet Vil. $\left(47.733824^{\circ} \mathrm{N} ; 51.574143^{\circ} \mathrm{E}\right)$, left bank of Ural River, supra-floodplain terrace with pigweed Anabasis aphyla, 14.06.1987, A.V. Ponomarev. - Turkozelotes mirandus: Holotype $\mathrm{O}^{7}$ (ZMMU), Russia, Rostov Area, Remontnoe Distr., Krasnopartisanskii Vil., Kurnikov Liman, salt marsh $\left(46.348939^{\circ} \mathrm{N} ; 43.215931^{\circ} \mathrm{E}\right), 21.05 .2009$, A.V. Ponomarev. Paratypes: $1 \sigma^{7}, 2$ 우 (PC, 18.37.1/1), same locality as of the holotype, 25.06.2010, A.V. Ponomarev; 1 우 (ZMMU), Russia, Rostov Area, Orlovskii Distr., Manytch Vil., 


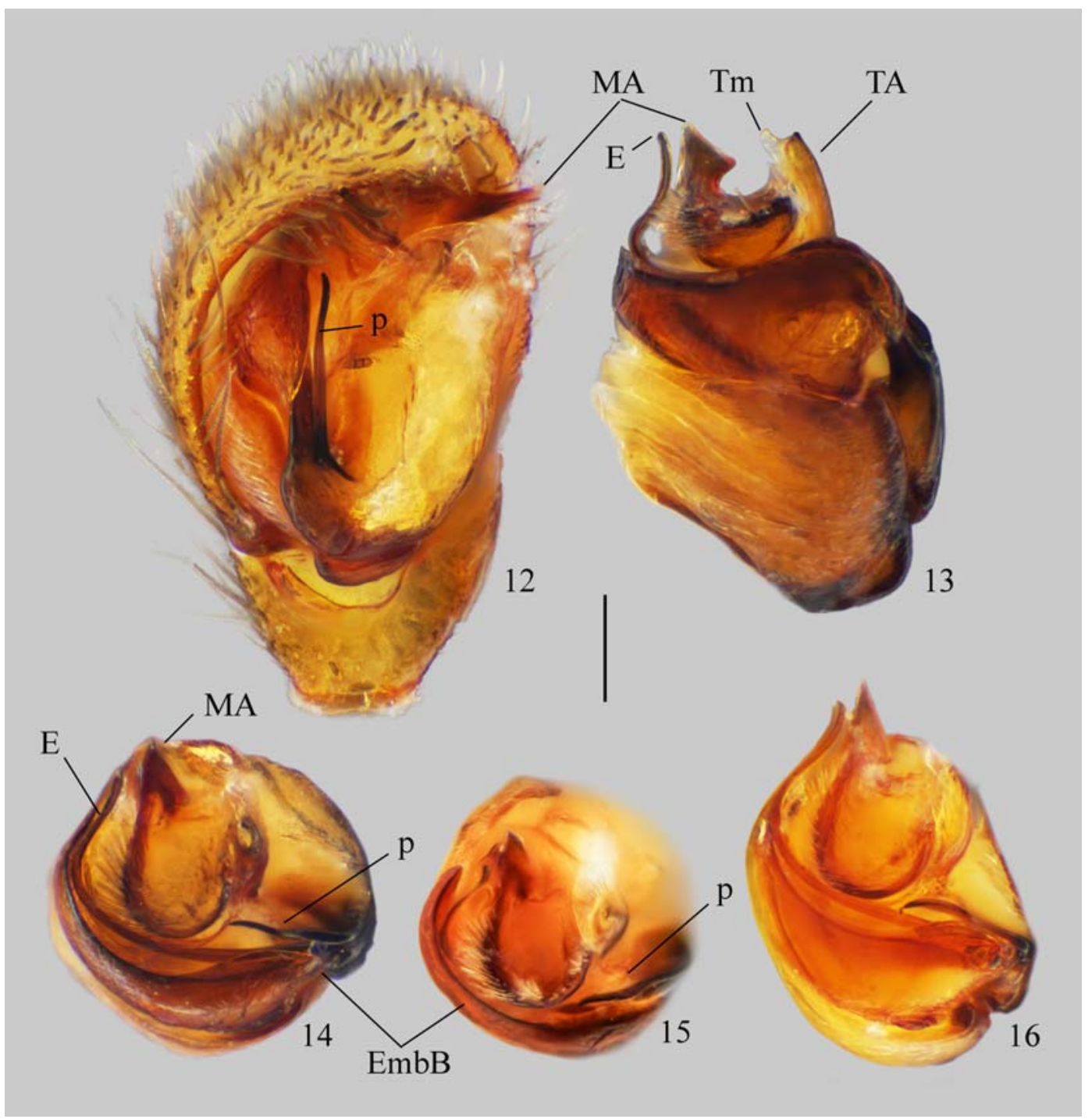

Figs 12-16. Male palp (12) and bulbus (13-16) of Turkozelotes kazachstanicus (Ponomarev et Tsvetkov, 2006) comb.n. from Rostov Area: 12 - ventro-apical view; 13 - dorsal view; 14,15 - apical view, different angles; 16 - dorso-apical view. Scale: $0.25 \mathrm{~mm}$. E embolus; EmbB — embolar base; MA — median apophysis; TA — terminal apophysis, Tm - terminal membrane; $p$ - embolar process.

Рис. 12-16. Пальпа самца (12) и бульбус (13-16) Turkozelotes kazachstanicus (Ponomarev et Tsvetkov, 2006) comb.n. из Ростовской области: 12 - вентро-апикально; 13 - дорсально; 14, 15 - апикально, разные ракурсы; 16 - дорсо-апикально. Масштаб: 0,25 мм. Е - эмболюс; ЕmbВ - база эмболюса; МА - медианный апофиз; ТА — терминальный апофиз; Tm терминальная мембрана; $\mathrm{p}$ - отросток эмболюса.

shore of Lake Gruzskoe, salt marsh $\left(46.429876^{\circ} \mathrm{N} ; 42.710919^{\circ} \mathrm{E}\right)$, 26.05.2010, A.V. Ponomarev.

OTHER MATERIAL. RUSSIA: $1 \sigma^{7}$ (PC: 18.37.1/2), Rostov Area, Orlovskii Distr., Manytch Vil., Manytch-Gudilo Lake, Vodnyi Island $\left(46.8^{\circ} \mathrm{N} ; 42.833333^{\circ} \mathrm{E}\right)$, salt marsh, 9.05.2012, Z.G Prichutova; $2 \sigma^{7} \sigma^{7}, 2$ 우 (ZMMU), $2 \sigma^{7} \sigma^{7}, 1$ ( 1 (PC: 18.37.1/3), same locality, salt marsh, 25.06-19.08.2016, E. Eremenko. - KAZAKHSTAN: 3 우 (PC: 18.37.1/4), Kostanay Area, Altyn Dala Nature Reserve, Rakhmet $\left(49.267778^{\circ} \mathrm{N} ; 65.274167^{\circ} \mathrm{E}\right)$, bank of Uly-Zhilanshi River, salt marsh, 18.05.2014, T.M. Bragina. AZERBAIJAN: 1 of (PC: 18.37.1/5), Nakhichevan, Sharur Dist., shore of Arpachay Reservoir $\left(39.176467^{\circ} \mathrm{N} ; 45.365239^{\circ} \mathrm{E}\right), 4.05$. 2018, N.Yu. Snegovaya.

COMMENTS. As indicated above, the holotype female of $Z$. kazachstanicus lacks the epigyne, which is a key taxonomic character. Yet, we have synonimyzed T. mirandus with $Z$. kazachstanicus and established a new combination
Turkozelotes kazachstanicus comb.n. due to the following reasons: the conformation of the epigyne of Z. kazachstanicus (as seen in Fig. 7, and based on the first author's memory) is identical to that of the paratype of T. mirandus (Fig. 8); the female body size (body 3.4-3.7 $\mathrm{mm}$ long, carapace 1.4-1.5 $\mathrm{mm}$ long and $1.1 \mathrm{~mm}$ wide); the body colouration (carapace brown to dark grey, with yellow patches, abdomen grey); the same leg armature (two pairs of ventral spines on metatarsi I and II); identical eye shape, size and position (small eyes situated compactly, both eye rows straight, median eyes of the second row elongate-oval); and finally the same habitat preferences (saline biotopes).

A comparison of the male palp conformation of $T . k a$ zachstanicus (Figs 1-6, 12-16) with that of T. mccowani (cf. figs 58-67 in Chatzaki [2018]) has shown no differences in the shape of tibial apophyses. In T. kazachstanicus, the 


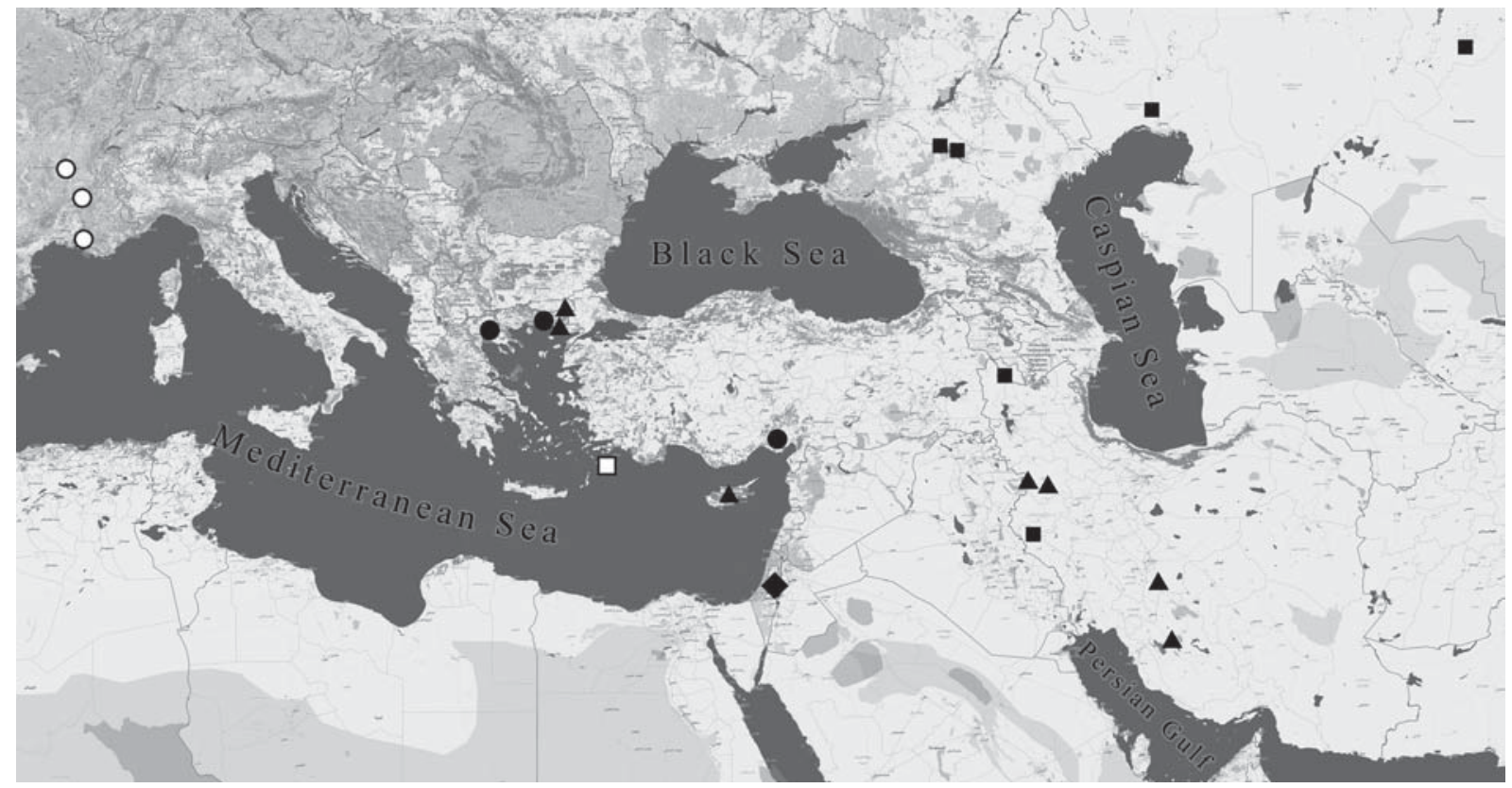

Map. Distribution of the Turkozelotes species: T. microb (filled circle), T. adallum comb.n. (rhomb), T. attavirus (open square), T. kazachstanicus comb.n. (filled square), T. mccowani (triangle), T. noname (open circle). After Levy [2009]; Kovblyuk et al. [2009]; Chatzaki \& Russell-Smith [2017]; Chatzaki [2018]; Chatzaki \& van Keer [2019]; Zamani et al. [2018, 2019, 2020]; Mazzia \& Cornic [2020] and present data.

Карта. Распространение видов Turkozelotes: T. microb (залитый круг), T. adallum comb.n. (ромб), T. attavirus (незалитый квадрат), T. kazachstanicus comb.n. (залитый квадрат), T. mсcowani (треугольник) и T. nоname (незалитый круг). По Levy [2009]; Kovblyuk et al. [2009]; Chatzaki \& Russell-Smith [2017]; Chatzaki [2018]; Chatzaki \& van Keer [2019]; Zamani et al. [2018, 2019, 2020]; Mazzia \& Cornic [2020] и оригинальные данные.

tibial apophysis varies in its shape (Figs 4-6). It is possible that such/similar variation also exists in T. mccowani but was not indicated by Chatzaki [2018], who studied a long series of males. The bipartite spermathecae are described for the females of $T$. mccowani: "spermathecae with ventral bean-shaped chambers (S1 in Fig. 27) and with dorsal round chambers (S2 in Fig. 28) leading to coiled tubular copulatory ducts" [Chatzaki, Russell-Smith, 2017: 247]. In T. kazachstanicus, the spermathecae are small, rounded, unipartite (Figs 9,10), but could look like bipartite in ventral view (Fig. 8) due to a loop-like sinuous duct that is better visible in dorsal view (Figs 10, 11). In addition, the position of epigynal anterior margins ("pockets") is slightly different in two species. Based on the mentioned differences, it seems safe not to synonymize $T$. mccowani with $T$. kazachstanicus for the time being A definite decision can be drawn after a direct comparison of the types and additional Mediterranean materials on T. mccowani.

HABITAT. Russia, Rostov Area: salt marshes. Kazakhstan, northern Caspian Region: saline biotopes along Ural River; Kostanai Area: saline biotopes along Uly-Zhilanshi River.

DISTRIBUTION. Russia: Rostov Area; Kazakhstan: northern Caspian Region, the south part of Kostanai Area; Azerbaijan: Nakhichevan; Iran: Ilam Province (Map).

\section{Turkozelotes adullam (Levy, 2009) comb.n. ex Drassyllus Map.}

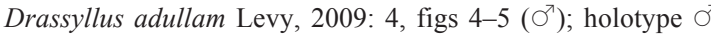
in the Hebrew University of Jerusalem (HUJ15529), not examined.
COMMENTS. As stated in the original description [Levy, 2009: 5], "the palpus with the median trajectory of the embolus and the shape of the tibial apophysis in particular, clearly distinguish $D$. adulam from all other Drassyllus species". Based on the original figure [Levy, 2009, fig. 4], the retrolateral position of embolic origin, its trajectory (embolus crosses tegulum from its dorsal side, running towards its retrolateral side), the male palpal tibia protruding retrolateard and the wide tibial apophysis unambiguously indicate the affiliation of this species with Turkozelotes; hence a new combination is proposed: Turkozelotes adullam comb.n. This species is close to T. kazachstanicus and T. mccowani, but can be easily distinguished from both by the smaller size and the shape of the male palp tibial apophysis; yet, the embolic origin and trajectory [Levi, 2009, fig. 4] are very similar to those of T. kazachstanicus [Ponomarev, Dvadnenko, 2011, fig. 1a-b]. (Map).

DISTRIBUTION. Israel: Adullam Reserve [Levy, 2009]

\section{Discussion}

To date, six species of Turkozelotes have been described (Table). Of them, T. mccowani is likely to be a junior synonym of T. kazachstanicus, but a re-examination of the type material of both species as well as additional Mediterranean materials on T. mccowani is required. In the description of $T$. noname, Mazzia, Cornic [2020] indicated that in its copulatory organs this species is similar to T. kazachstanicus and 
Table. Species composition and distribution of Turkozelotes Kovblyuk et Seyyar, 2009. Таблица. Видовой состав и распространение Turkozelotes Kovblyuk et Seyyar, 2009.

\begin{tabular}{|c|c|c|c|c|c|}
\hline \multirow[b]{2}{*}{ Species name } & \multirow{2}{*}{$\begin{array}{l}\text { Sexes } \\
\text { known }\end{array}$} & \multicolumn{3}{|c|}{ Zoogeographical regions } & \multirow[b]{2}{*}{ References } \\
\hline & & Mediterranean & $\begin{array}{l}\text { Eastern } \\
\text { European }\end{array}$ & Irano-Turan & \\
\hline $\begin{array}{l}\text { T. adullam (Levy, 2009), } \\
\text { comb.n. }\end{array}$ & $\delta$ & Israel & & & Levy, 2009 \\
\hline $\begin{array}{l}\text { T. attavirus Chatzaki, } \\
2019\end{array}$ & $\delta q$ & $\begin{array}{l}\text { Greece } \\
\text { (Rhodes) }\end{array}$ & & & $\begin{array}{l}\text { Chatzaki, Van Keer, } \\
2019\end{array}$ \\
\hline $\begin{array}{l}\text { T. kazachstanicus } \\
\text { (Ponomarev et Tsvetkov, } \\
\text { 2006), comb.n. }\end{array}$ & $\partial q$ & & $\begin{array}{l}\text { Russia } \\
\text { (Rostov } \\
\text { Area) }\end{array}$ & $\begin{array}{l}\text { Kazakhstan } \\
\text { (Atyrau and } \\
\text { Kostanay } \\
\text { areas); } \\
\text { Azerbaijan } \\
\text { (Nakhichevan); } \\
\text { Iran (Ilam } \\
\text { Province) }\end{array}$ & $\begin{array}{l}\text { Ponomarev, } \\
\text { Tsvetkov, 2006; } \\
\text { Ponomarev, } \\
\text { Dvadnenko, 2011; } \\
\text { Zamani et al., 2018; } \\
\text { present data }\end{array}$ \\
\hline $\begin{array}{l}\text { T. mccowani (Chatzaki et } \\
\text { Russel-Schmidt, 2017) }\end{array}$ & d우 & $\begin{array}{l}\text { Cyprus; } \\
\text { Greece }\end{array}$ & & $\begin{array}{l}\text { Iran } \\
\text { (Kurdistan, } \\
\text { Fars provinces) }\end{array}$ & $\begin{array}{l}\text { Chatzaki, Russel- } \\
\text { Schmidt, 2017; } \\
\text { Chatzaki, 2018; } \\
\text { Zamani et al., 2019, } \\
2020\end{array}$ \\
\hline $\begin{array}{l}\text { T. microb Kovblyuk et } \\
\text { Seyyar, } 2009\end{array}$ & $\delta^{2}+q$ & $\begin{array}{l}\text { Turkey } \\
\text { (Adana } \\
\text { Province); } \\
\text { Greece }\end{array}$ & & & $\begin{array}{l}\text { Kovblyuk et al., } \\
2009 \text {; Chatzaki, } \\
2018\end{array}$ \\
\hline $\begin{array}{l}\text { T. noname Mazzia et } \\
\text { Cornic, } 2020\end{array}$ & șo & $\begin{array}{l}\text { France } \\
\text { (Provence- } \\
\text { Alpes-Côte } \\
\text { d'Azur) }\end{array}$ & & & $\begin{array}{l}\text { Mazzia, Cornic, } \\
2020\end{array}$ \\
\hline
\end{tabular}

T. mccowani but different from T. attavirus and $T$. microb. Yet, T. adullam is also close to T. kazachstanicus and T. mccowani. Therefore, it is safe to propose two species groups within Turkozelotes based on the structure of copulatory organs: the kazachstanicus group consisting of T. adullam, T. kazachstanicus, T. mccowani and $T$. noname which possess the large, broadened apically and directed dorsad male palp tibial apophysis, the large and wide epigynal groove and two widely separated epigynal "pockets" (=anterior margins); and the attavirus group containing T. attavirus and T. mi$c r o b$ and having the comparatively small, directed apicad male palp tibial apophysis, the small epigynal groove that is slightly longer than wide (or slightly wider than long) and the anterior hood situtated at the anterior part of the epigyne.

The genus is distributed mainly in the region of Ancient Mediterranean (Map); only T. kazachstanicus is known outside its limits, being reported from the vast area from Armenian Upland to north-west Kazakhstan. The species from the kazachstanicus group define the limits of the generic range: T. noname - the western, T. kazachstanicus - the northern and the eastern, T. adullam - the southern.

Acknowledgements. We are deeply obliged to T.M. Bragina (Kostanai Pedagogical Institute, Kostanai, Kazakh- stan), E.A. Eremenko (Souther Federal University, Rostovon-Don, Russia), Z.G. Prishutova (Rostov-on-Don, Russia), N.Yu. Snegovaya (Institute of Zoology NAS of Azerbaijan, Baku Azerbaijan) for the material provided for our study. S.L. Esyunin (Perm State University, Perm, Russia) is especially acknowledged for taxonomical consultation.

Study of A.V. Ponomarev amd V.Yu. Shmatko is supported with Southern Scientific Centre of the Russian Academy of Sciences Project No. AAAA-A19-119011190176-7. The work of K.G. Mikhailov is supported by MSU Zoological Museum State Program.

\section{References}

Chatzaki M. 2018. On the ground spider genera Marjanus gen. n., Lasophorus gen. n. and Turkozelotes Kovblyuk \& Seyyar, 2009 (Araneae: Gnaphosidae) from Greece // Zootaxa. Vol.4392. No.3. P. 521-545. DOI: 10.11646/zootaxa.4392.3.5

Chatzaki M., Russell-Smith A. 2017. New species and new records of ground spiders (Araneae: Gnaphosidae) from Cyprus // Zootaxa. Vol.4329. No.3. P.237-255. DOI: 10.11646/zootaxa.4329.3.3

Chatzaki M., van Keer J. 2019. Ground spiders (Araneae: Gnaphosidae, Liocranidae, Prodidomidae) from the Greek islands Rodos, Symi and Karpathos, with the description of new species // Zootaxa. Vol.4646. No.3. P.434-460. DOI: 10.11646/ zootaxa.4646.3.2

Kovblyuk M.M., Seyyar O., Demir H., Topçu A. 2009. New taxonomic and faunistic data on the gnaphosid spiders of Turkey (Aranei: Gnaphosidae) // Arthropoda Selecta. Vol.18. No.3-4. P.169-187. 
Levy G. 2009. New ground-spider genera and species with annexed checklist of the Gnaphosidae (Araneae) of Israel // Zootaxa. Vol.2066. P.1-49.

Mazzia C., Cornic J.-F. 2020. Turkozelotes (Araneae, Gnaphosidae) un nouveau genre pour la France et description de Turkozelotes noname n. sp. // Revue Arachnologique, série 2. No.7. P.35-43.

Ponomarev A.V., Dvadnenko K.V. 2011. [A new species of the spiders genus Turkozelotes Kovblyuk et Seyyar, 2009 (Aranei Gnaphosidae) from the Rostov region] // Vestnik Yuzhnogo nauchnogo tsentra. Vol.7. No.2. P.108-110 [in Russian, with English summary].

Ponomarev A.V., Tsvetkov A.S. 2006. [New and rare spiders of family Gnaphosidae (Aranei) from a southeast of Europe] // Caucasian Entomological Bulletin. Vol.2. No.1. P.5-13. DOI: 10.23885/1814-3326-2006-2-1-5-13 [in Russian, with English summary].
Zamani A., Dimitrov D., Weiss I., Alimohammadi S., Rafiei-Jahed R., Esyunin S.L., Moradmand M., Chatzaki M., Marusik Yu.M. 2020. New data on the spider fauna of Iran (Arachnida: Araneae), part VII // Arachnology. Vol.18. No.6. P.569-591. DOI: 10.13156/arac.2020.18.6.569

Zamani A., Mirshamsi O., Mohammadi Kashani G., Karami L. 2018. New data on the spider fauna of Iran (Arachnida: Araneae), part V // Iranian Journal of Animal Biosystematics. Vol.13 (for 2017). No.2. P.183-197. DOI: 10.22067/ijab.v13i2.72404 Zamani A., Tanasevitch A.V., Nadolny A.A., Esyunin S.L., Marusik Yu.M. 2019. New data on the spider fauna of Iran (Arachnida: Aranei). Part VI // Euroasian Entomological Journal. Vol.18. No.4. P.233-243. DOI: 10.15298/euroasentj.18.4.01

Responsible editor D.V. Logunov 